\title{
ROLE OF VESTIBULAR EVOKED MYOGENIC POTENTIALS AS AN INDICATOR OF RECOVERY IN PATIENTS WITH BENIGN PAROXYSMAL POSITIONAL VERTIGO
}

\author{
Tihana Mendešr,2, Siniša Maslovara ${ }^{1,2}$, Andrijana Včeva ${ }^{2,3}$ and Silva Butković Soldo ${ }^{4,5}$ \\ ${ }^{1}$ Department of Otorhinolaryngology, Vukovar General County Hospital, Vukovar, Croatia; \\ ${ }^{2}$ Department of Otorhinolaryngology and Maxillofacial Surgery, School of Medicine, Josip Juraj Strossmayer \\ University of Osijek, Osijek, Croatia; ${ }^{3}$ University Department of ENT and Head and Neck Surgery, \\ Osijek University Hospital Centre, Osijek, Croatia; ${ }^{4}$ University Department of Neurology, Osijek University \\ Hospital Centre, Osijek, Croatia; ${ }^{5}$ Department of Neurology, School of Medicine, Josip Juraj Strossmayer \\ University of Osijek, Osijek, Croatia
}

SUMMARY - Ocular vestibular evoked myogenic potentials (oVEMP) and cervical VEMP (cVEMP) are newer diagnostic methods, which allow an insight into the otolith senses. Our aim was to determine changes in certain parameters of the VEMP wave complex after successfully performed repositioning procedure, as an indicator of the state of recovery in patients with benign paroxysmal positional vertigo (BPPV). This may confirm the theory of otolith returning into the area of otolithic senses. The study included 48 patients with unilateral posterior semicircular canal BPPV. On their first arrival, otoneurological examinations, oVEMP and cVEMP tests were performed. The same were included in follow up check-ups scheduled at seven days and six months after successful implementation of Epley maneuvers. The initial measurement revealed a significantly reduced amplitude of oVEMP on the affected side. On the 7-day measurement, the amplitude increase was observed on the affected side, with significant reduction in the amplitude ratio $(\mathrm{p}=0.693)$, which reached statistical significance on the last measurement at 6 months $(\mathrm{p}=0.006)$. These findings confirmed the hypothesis of the return of otoconia into the utricular area.

Key words: Vestibular evoked myogenic potentials; Otolithic membrane; Benign paroxysmal positional vertigo; Semicircular canals; Quality of life

\section{Introduction}

Benign paroxysmal positioning vertigo (BPPV) is the most common cause of peripheral forms of vertigo ${ }^{1}$. According to various sources, BPPV accounts for $20 \%$ $30 \%$ of vertigo cases in the general population, while its share in older population rises to more than $50 \%$ according to some authors. This is a growing public health

Correspondence to: Tihana Mendeš, MD, Department of Otolaryngology, General County Hospital Vukovar, Županijska 35, HR32000 Vukovar, Croatia

E-mail: tvesligaj@gmail.com

Received September 7, 2016, accepted September 14, 2017 problem, as it ever more frequently affects the younger, active population and greatly influences the quality of life. Vertigo can also be a symptom of many neurological diseases such as multiple sclerosis, and has a negative impact on the patient health-related quality of life ${ }^{2,3}$. The vast majority of patients can be successfully treated with Epley repositioning maneuver, which is most commonly used in clinical practice when the posterior semicircular canal (PC) is affected ${ }^{4-6}$.

In a certain number of patients, there is recurrence of the disease after a while, which usually affects the same semicircular canal. Relapses occur in approximately $30 \%$ of patients after one year ${ }^{7-9}$. According to 
the available literature, Brandt et al. found $50 \%$ of recurrence in their retrospective study on 125 patients, six to 17 years subsequent to the diagnosis, $80 \%$ of which occurred after one year. They recorded almost double incidence of relapse in patients in the sixth decade of life as compared with those in the seventh decade. The patients that had an eight-year symptomfree period had no recurrence of the disease afterwards ${ }^{10}$.

Otolithic receptors respond to linear acceleration or/and deceleration ${ }^{11}$, and the hardest challenge for clinical practice is to measure linear acceleration in patients in the easiest and safest way.

Vestibular evoked myogenic potentials (VEMP) are one of the newer diagnostic methods which allows an insight into the otolith senses. This diagnostic method relies on the fact that the utricle and saccule are not only sensitive to linear acceleration, but also to loud sound. The founder of the idea on the sensitivity of vestibular organ to the sound stimuli was the Italian physiologist Dr Pietro Tullio (1881-1941). The first research of the effects of sound and vibration on the vestibular system in humans was performed by Ribarić et al. ${ }^{12}$. Ocular vestibular evoked myogenic potential (oVEMP) reflect the excitatory utricular response and are used to evaluate the ascending vestibular pathway, as the crossed vestibulo-ocular reflex ${ }^{13}$ pointed to the shift of the contralateral eye to sound stimulation of the vestibular system ${ }^{14}$, demonstrating that acoustic stimulation of the otoliths leads to oVEMP. However, there still are doubts about whether oVEMP records changes exclusively in the utriculus or also in the sacculus $^{15}$. Anyway, oVEMP depend on the state of the upper part of the vestibular nerve ${ }^{16}$. The utricular signals are transmitted through the superior vestibular nerve to the superior vestibular region in the brainstem, crossing to the oculomotor nucleus and to the extraocular muscles. Cervical vestibular evoked myogenic potentials (cVEMP) assess the descending vestibular pathway as an ipsilateral sacculocollic reflex ${ }^{17,18}$. They measure saccular function representing inhibitory responses conducted through the inferior vestibular nerve to the accessory nucleus in the brainstem and via accessory nerves to the ipsilateral sternocleidomastoid muscle ${ }^{19}$. Successful repositioning procedure is expected to result in reduction of disease symptoms, increase in the peak-to-peak amplitude on the affected side, leveling with the unaffected side, as well as lower- ing of AR after a while because some time is needed for otolith embedding in the otolithic membrane.

In the past few years, the number of studies related to VEMP and BPPV has increased, as VEMP is the only clinical test for vestibular system which provides information on otolith function.

Sreenivasan et al. ${ }^{20}$ conclude that disease pathology is indicated as absent response from ipsilateral ear, prolonged latency of $\mathrm{n} 23$, and decreased peak-to-peak amplitude (p13, n23). Hui et al. ${ }^{21}$ did not analyze the latency and amplitude of the waves in c/oVEMP and defined abnormal c/oVEMP only as absent responses. So far, none of the studies has clearly confirmed which parameter of the cVEMP and/or oVEMP wave complex is statistically important for clinical interpretation because most studies involved an insufficient number of subjects.

Our aim was to determine whether there are changes in certain parameters of the VEMP wave complex after successfully performed repositioning procedure, as well as between subjects with recurrent and non-recurrent disease.

\section{Patients and Methods}

\section{Patients}

This prospective clinical study was performed at the Department of Otorhinolaryngology, Vukovar General County Hospital. A total of 48 patients with unilateral PC-BPPV were included in the study. $\mathrm{Pa}-$ tients with anterior or horizontal canal BPPV, or bilateral BPPV were excluded to standardize the study and to include a homogeneous population. Inclusion criterion was a history of short-lasting ( $\leq 60 \mathrm{~s})$, positive Dix-Hallpike test using Frenzel glasses (vertigo provoked by head position changes relative to gravity). Exclusion criteria were any kind of hearing damage, unilateral weakness $\geq 25 \%$ and directional preponderance $\geq 35 \%$ in the caloric test, and positive Ménière disease or vestibular migraine.

Information was collected during diagnostic evaluation of the patients. All patients underwent standardized otoneurologic examination. Also, audiologic examination (Pure-tone audiometry, tympanometry), entire videonystagmography (VNG) battery, and cervical and ocular VEMP testing were performed.

The study was performed in accordance with the Helsinki II Declaration. All participants gave their informed consent before inclusion in the study. 
Full videonystagmography battery was performed by the VO425 device (Interacoustics, Assens, Denmark).

The VEMP was determined using Eclipse Platform (Interacoustics, Assens, Denmark), and electromyography (EMG) (System Otoacces, Montreal, Canada). The acoustic stimulus was made monoaurally by Insert earphones ABR 3A (Interacoustics, Assens, Denmark), with earplugs (3M Auditory Systems, Indianapolis, USA). One type of air-conducted stimuli was used, $5.1 \mathrm{~ms}, 95 \mathrm{~dB}$ nhL clicks of negative polarity and $500 \mathrm{~Hz}, 95 \mathrm{~dB}$ nhL tone bursts of negative polarity with a linear envelope ( $2 \mathrm{~ms}$ rise/fall time, $1 \mathrm{~ms}$ plateau). Two hundred sweeps were averaged for each test. The following values were compared: latencies of $\mathrm{p}$ and $\mathrm{n}$ wave, peak-to-peak amplitudes and amplitude ratio (AR) in both groups of subjects, and the relation of all measured parameters between the groups.

In the interpretation of VEMP results, we used the following parameters: $\mathrm{p}$ and $\mathrm{n}$ wave latency, peak-topeak amplitude size and interneural AR expressed in percentages. As a clinically significant parameter, we took the absolute value of the peak-to-peak amplitude, which is double in size of the other one ( $A R \geq 35 \%)$.

The first follow up examination after the repositioning procedure was scheduled after 7 days, with recompletion of the questionnaire, Dix-Hallpike, VNG, cVEMP and oVEMP. Follow up examinations include filling out the questionnaire and Dix-Hallpike test repeated every 7 days (4 times at the most) until negative result is recorded. The last check-up was scheduled at six months after the successful repositioning maneuver and consisted of the same procedures and questionnaires as the first one.

\section{Statistical analysis}

Descriptive statistics methods were used for description of the distribution of the frequencies of the study variables. All variables were tested for normality of distribution with Kolmogorov-Smirnov test, and according to the results, parametric or nonparametric methods were applied. The values of continuous variables were expressed as arithmetic mean and standard deviation for normally distributed variables, and by median and range for non-normally distributed variables. Nominal points were presented with distribution of the occurrence by groups and percentage.
Student's T-test was used to determine differences between two independent samples, while Student's Ttest for dependable samples was used to determine differences between two measurements (Wilcoxon test for nonparametric distribution). Analysis of variance for repeated measurements (nonparametric Friedman test) was used to determine differences of dependent samples according to the time of measurement ( 3 and more).

The Receiver Operating Characteristic (ROC) analysis was applied to determine optimal borderline values, the area under the ROC curve (AUC), specificity and sensitivity of the tested parameters in cases of relapse. The influence of more predictors on the positive test and on the recurrence was evaluated by logistic regression. The level of association was assessed by Pearson or Spearman coefficient of correlation, depending on the normality of distribution. The $\chi^{2}$-test and Fisher exact test were used to determine differences between proportions. The level of significance was set at $\mathrm{a}=0.05$.

\section{Results}

Forty-eight patients with typical unilateral BPPV were included ( 33 women, median age 63, range 53-69 years). In 33 (68.7\%) cases, the right side was affected. All 48 (100\%) patients underwent two repositioning procedures, while two additional repositioning procedures were required in 16 (33.33\%) patients because the vertiginous problems persisted and the Dix-Hallpike test was still positive. After the last repositioning procedure applied, complete withdrawal of symptoms and negative Dix-Hallpike test were recorded in all 48 (100\%) patients. Follow up examination at 6 months was conducted in all 48 (100\%) patients.

\section{cVEMP}

In all patients, three were no statistically significant changes in the size of p13 latency on the affected side before and after successful repositioning procedure $(p=0.203 ; p=0.310)$. The same applies to the affected side $n 23$ latency ( $\mathrm{p}=0.646 ; \mathrm{p}=0.946)$. The 6 -month follow up showed no significant differences in the size of latency $\mathrm{p} 13$ and $\mathrm{n} 23$ wave either $(\mathrm{p}<0.950 ; \mathrm{p}=0.599$; $\mathrm{p}=0.893 ; \mathrm{p}=0.074$ ).

After successful implementation of the repositioning procedure, there was no significant increase in the 
Table 1. Median value of the cVEMP peak-to-peak amplitude

\begin{tabular}{|c|c|c|c|c|c|}
\hline \multirow[b]{2}{*}{ cVEMP } & \multicolumn{2}{|l|}{ Non-affected } & \multicolumn{2}{|l|}{ Affected } & \multirow[b]{2}{*}{$\mathrm{p}^{\dagger}$} \\
\hline & \begin{tabular}{|l} 
Median \\
$(25 \%-75 \%)$
\end{tabular} & $\mathrm{p}^{*}$ & $\begin{array}{l}\text { Median } \\
(25 \%-75 \%)\end{array}$ & $\mathrm{p}^{*}$ & \\
\hline $\begin{array}{l}\text { Amplitude } \\
\text { Before Epley } \\
\text { After Epley } \\
\text { Three days after Epley } \\
\text { Six months after Epley }\end{array}$ & $\begin{array}{l}39.64(18.11-81.77) \\
41.3(20.92-74.88) \\
33.15(25.08-64.8) \\
37.46(25.74-84.34)\end{array}$ & 0.264 & $\begin{array}{l}34.13(23.32-60.4) \\
32.02(20.91-59.35) \\
24.26(14.88-42.13) \\
27.02(20.46-62.09)\end{array}$ & 0.631 & $\begin{array}{l}0.634 \\
0.227 \\
0.243 \\
0.065\end{array}$ \\
\hline
\end{tabular}

*Friedman's test; ${ }^{\dagger}$ Mann Whitney’s U test; cVEMP = cervical vestibular evoked myogenic potentials

Table 2. Mean cVEMP amplitude ratio measured

\begin{tabular}{|l|l|l|l|l|l|l|}
\hline AR & Before Epley & After Epley & After 3 days of Epley & p value & After 6 months of Epley & $p$ value* \\
\hline & $0.31(0.16-0.45)$ & $\begin{array}{l}0.25 \\
(0.07-0.43)\end{array}$ & $\begin{array}{l}0.32 \\
(0.23-0.38)\end{array}$ & $0.640^{\dagger}$ & $\begin{array}{l}0.14 \\
(0.05-0.22)\end{array}$ & 0.406 \\
\hline
\end{tabular}

*Friedman's test; ${ }^{\dagger}$ Wilcoxon test; cVEMP = cervical vestibular evoked myogenic potentials; AR = amplitude ratio

Table 3. Median value of the oVEMP peak-to-peak amplitude

\begin{tabular}{|c|c|c|c|c|c|}
\hline \multirow[b]{2}{*}{ oVEMP } & \multicolumn{2}{|l|}{ Affected } & \multicolumn{2}{|l|}{ Non-affected } & \multirow[b]{2}{*}{$\mathrm{p}^{\dagger}$} \\
\hline & $\begin{array}{l}\text { Median } \\
(25 \%-75 \%)\end{array}$ & $\mathrm{p}^{*}$ & \begin{tabular}{|l} 
Median \\
$(25 \%-75 \%)$
\end{tabular} & $\mathrm{p}^{*}$ & \\
\hline Amplitude & & & & & \\
\hline Before Epley & $1.64(0.98-2.7)$ & & $1.57(0.94-2.37)$ & & 0.759 \\
\hline After Epley & $1.61(1.28-2.67)$ & & $1.64(1.19-2.66)$ & & 0.901 \\
\hline Day 3 after Epley & $2.21(1.36-3.06)$ & 0.919 & $1.97(1.22-3.01)$ & 0.993 & 0.710 \\
\hline Month 6 after Epley & $2.1(1.25-3.14)$ & & $1.9(1.03-2.6)$ & & 0.600 \\
\hline
\end{tabular}

*Friedman's test; ${ }^{\dagger}$ Mann Whitney’s U test; oVEMP = ocular vestibular evoked myogenic potentials

\section{Table 4. Mean oVEMP amplitude ratio measured}

\begin{tabular}{|l|l|l|l|l|l|l|}
\hline AR & Before Epley & After Epley & After 3 days of Epley & p value & After 6 months of Epley & $p$ value* \\
& $\begin{array}{l}0.21 \\
(0.11-0.42)\end{array}$ & $\begin{array}{l}0.18 \\
(0.08-0.37)\end{array}$ & $\begin{array}{l}0.33 \\
(0.25-0.42)\end{array}$ & $0.011^{\dagger}$ & $\begin{array}{l}0.14 \\
(0.04-0.24)\end{array}$ & 0.039 \\
\hline
\end{tabular}

*Friedman's test; ${ }^{\dagger}$ Wilcoxon test; oVEMP = ocular vestibular evoked myogenic potentials; $\mathrm{AR}=$ amplitude ratio

Table 5. Prediction of the likelihood that patients will develop recurrence - univariate regression analysis

\begin{tabular}{|l|l|l|l|l|l|l|}
\hline $\begin{array}{l}\text { Parameter } \\
\text { (after 6 months) }\end{array}$ & $\beta$ & $\begin{array}{l}\text { Standard } \\
\text { deviation }\end{array}$ & Wald & $p$ & $\begin{array}{l}\text { Likelihood ratio } \\
(\operatorname{Exp} \beta)\end{array}$ & $\begin{array}{l}\text { 95\% CI } \\
\text { za Exp } \beta\end{array}$ \\
\hline $\begin{array}{l}\text { cVEMP - interaural } \\
\text { amplitude ratio } \\
\text { oVEMP - interaural } \\
\text { amplitude ratio }\end{array}$ & 6.067 & 2.387 & 6.461 & 0.011 & 431.5 & $4.01-46428.7$ \\
\hline
\end{tabular}

95\% CI = 95\% confidence interval; cVEMP = cervical vestibular evoked myogenic potentials; oVEMP = ocular vestibular evoked myogenic potentials 
Table 6. Prediction of the likelihood that patients will develop recurrence-univariate regression analysis

\begin{tabular}{|l|l|l|l|l|l|l|}
\hline Parameter & $\beta$ & $\begin{array}{l}\text { Standard } \\
\text { deviation }\end{array}$ & Wald & $\mathrm{p}$ & $\begin{array}{l}\text { Likelihood ratio } \\
\text { (Exp } \beta)\end{array}$ & $\begin{array}{l}\text { 95\% CI } \\
\text { za Exp } \beta\end{array}$ \\
\hline $\begin{array}{l}\text { cVEMP - interaural } \\
\text { amplitude ratio } \\
\text { oVEMP - interaural } \\
\text { amplitude ratio } \\
\text { Constant }\end{array}$ & 7.007 & 3.125 & 5.028 & 0.025 & 1104.49 & $2.417-504758.95$ \\
\hline
\end{tabular}

95\% CI = 95\% confidence interval; $\mathrm{cVEMP}=$ cervical vestibular evoked myogenic potentials; oVEMP = ocular vestibular evoked myogenic potentials

absolute value of the amplitude either on the affected or on the unaffected side. The cVEMP amplitude absolute values are shown in Table 1 .

\section{Interaural amplitude ratio}

On the first measurement, $A R \geq 35 \%$ was recorded in half of the 48 patients. After first repositioning procedure, on the second measurement, the AR $<35 \%$ was found in $26(54.2 \%)$ patients. The third measurement was performed in $16(33.33 \%)$ patients, where the Dix-Hallpike test was positive after the first two failed repositioning maneuvers. The $\mathrm{AR}<35 \%$ was recorded in two (12.5\%) patients. At 6-month follow up, cVEMP AR $<35 \%$ was found in $32(66.7 \%)$ patients (Table 2).

\section{oVEMP}

In all patients, there were no statistically significant changes in the size of p15 latency on the affected side before and after successfully performed repositioning procedure $(\mathrm{p}=0.455 ; \mathrm{p}=0.343)$. The same applies to the affected side n10 latency ( $\mathrm{p}=0.787 ; \mathrm{p}=0.378)$. The 6-month follow up showed no significant differences in the size of latency p15 and n 10 waves either $(\mathrm{p}=0.893 ; \mathrm{p}=0.655 ; \mathrm{p}=0.223 ; \mathrm{p}=0.302)$.

After successful repositioning procedure, an increase in the absolute value of the amplitude between the first and second measurements was recorded on the affected side. The oVEMP amplitude absolute values are shown in Table 3.

\section{Interaural amplitude ratio}

On the first measurement, AR $\geq 35 \%$ with a preponderance in favor of the affected side was recorded in $35(72.9 \%)$ patients. On the second measurement, after the first repositioning procedure, $\mathrm{AR}<35 \%$ was obtained in $22(45.8 \%)$ patients. The third measurement, which was conducted in 16 patients that did not respond to the first repositioning procedure, $\mathrm{AR}<35 \%$ was found in three (18.8\%) patients. At 6-month follow up, AR $<35 \%$ was recorded in 35 (72.9\%) patients (Table 4).

\section{Recurrence}

After six months, vertiginous disturbances that matched the symptoms of BPPV recurred in nine (18.75\%) patients, as confirmed by positive Dix-Hallpike probe. In their findings, there was a statistically significant difference of cVEMP and oVEMP AR in relation to the subjects free from recurrence $(p=0.044$, $\mathrm{p}<0.001$ ). In patients with recurrence, the latency value of $\mathrm{p}$ and $\mathrm{n}$ wave at cVEMP-and so with oVEMP did not change significantly compared to those without recurrence at 6-month follow up.

\section{The role of test parameters in predicting recurrence (logistic regression)}

Only nine (18.75\%) patients had recurrence. Logistic regression evaluated the impact of individual predictors of the likelihood that they would be observed in patients that developed recurrence. Univariate regression analysis proved the oVEMP and cVEMP AR as a significant predictor (Table 5).

As a model, we observed predictors that were significant (cVEMP AR and oVEMP AR). The model was completely statistically significant (c2 $=24.31$, $\mathrm{p}<0.001$ ), indicating that patients may differ according to clinical picture. The model as a whole explained between 39.7\% (R 2 COX \& Snell) and 64.2\% (r2Negelkerke) of variance for the presence of clinical symptoms of recurrence, and accurately classified $81.3 \%$ of cases. The strongest predictor was oVEMP AR (Table 6). 
Table 7. ROC curve parameters with regard to clinical recurrence

\begin{tabular}{|l|l|l|l|l|l|l|}
\hline Parameter & Area under the curve & $95 \%$ CI & Sensitivity & Specificity & Cut-off & $p$ \\
\hline AR - cVEMP & 0.724 & $0.576-0.843$ & 66.7 & 89.7 & $>0.26$ & 0.082 \\
AR - oVEMP & 0.848 & $0.715-0.935$ & 77.8 & 94.9 & $>0.23$ & 0.002 \\
\hline
\end{tabular}

ROC curve = Receiver Operating Characteristic curve; 95\% CI = 95\% confidence interval; cVEMP = cervical vestibular evoked myogenic potentials; oVEMP = ocular vestibular evoked myogenic potentials; $\mathrm{AR}=$ amplitude ratio

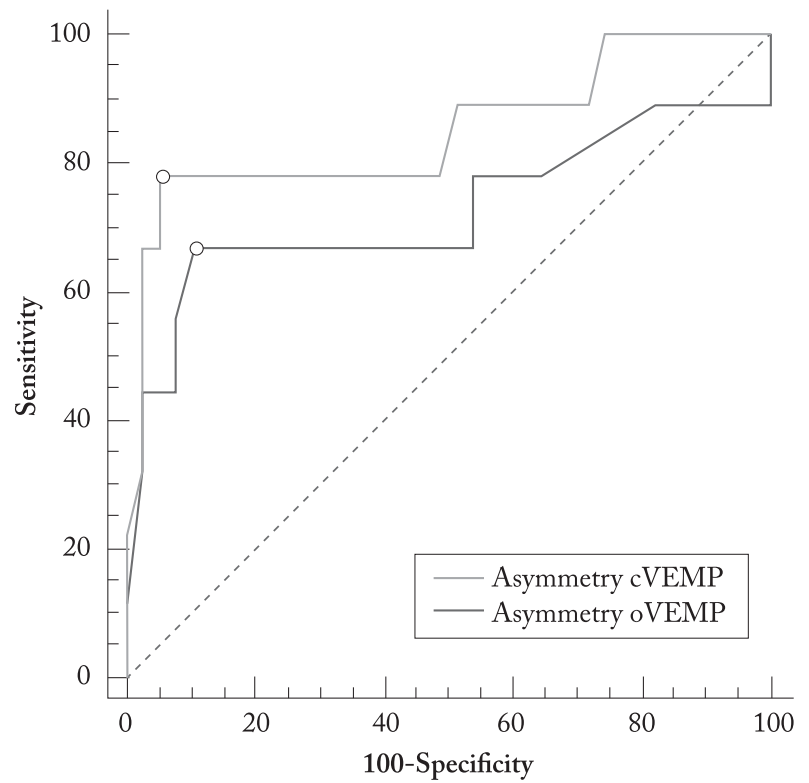

Fig. 1. ROC analysis of sensitivity, specificity and borderline values for the parameters observed according to clinical recurrence.

\section{The role of test parameters in predicting recurrence (ROC analysis)}

The ROC method was selected as a simple way to assess differences in each indicator according to clinical recurrence and was determined on the basis of specificity and sensitivity.

The method of ROC curve that gradually changes the cut-off values differentiating subjects with and without recurrence was employed to assess the values of particular parameters found by logistic regression to contribute significantly to the model. The cut-off point for a particular group of subjects was changed in order to objectively identify, by creating the ROC curve, the cut-off value that would best differentiate the groups compared. The results showed that oVEMP AR was the only significant diagnostic indicator of recurrence (77.8\% sensitivity, $94.9 \%$ specificity, $\mathrm{p}=0.002$ ) (Table 7 , Fig. 1).

\section{Discussion}

This prospective study including 48 patients showed an increase in the absolute value of the amplitude of the affected ear after the second repositioning procedure. The increase was considerable but not statistically significant. We can explain it with a large interquartile range and large average range between minimum and maximum. In the unaffected ear, there was no significant increase in the absolute value of the amplitude.

A significant increase in the amplitude on the affected side occurred after repositioning procedure at oVEMP points to the return of detached otoconia just in the area of utricle. After the first repositioning procedure, there was no increase in the absolute value of the amplitude at the affected ear. The explanation might lie in the histologic structure of the cupula utricle. Otoconial mass is made of thousands of otoconia and overlaid by an otoconial membrane. The upper part of the membrane is dense. On the opposite side, the lower part is more rigid and leads to linear force transduction. Reduced oVEMP is thought to originate from partial degeneration of the utricular hair cells ${ }^{22}$. Bremova et al. ${ }^{23}$ measured oVEMP amplitudes before and after Epley maneuvers and found significant increase in the amplitudes following the maneuvers whilst the cVEMPs had no amplitude change. These findings support the theory that utricular function is more damaged than saccular function.

In cVEMPs, no statistically significant increase in the absolute value of the amplitude was observed in either unaffected or affected ear after the first repositioning procedure. This result suggested that there was no change in the saccule function because there was no return of otoconia, the presence of which would increase the absolute value of the amplitude. This can be explained by the anatomical structure of the otolithic senses. The utricle and saccule are connected with the utriculosaccular duct ${ }^{24}$. The mean diameter of the en- 
dolymphatic duct is $0.16 \times 0.41 \mathrm{~mm}$ at the internal aperture of the vestibular aqueduct and $0.09 \times 0.20 \mathrm{~mm}$ at the isthmus ${ }^{25}$. The endolymphatic valve allows the endolymph flow from the utricle to the saccule, but not vice versa ${ }^{26}$.

From the clinical point of view, oVEMP appears to be better suited for testing PC-BPPV than cVEMP ${ }^{27}$. In $33(68.8 \%)$ cases, the right side was affected. One of the explanations is sleeping habit on the right side in most people. In the literature, a higher incidence of BPPV of the right labyrinth in relation to the left one is reported ${ }^{28}$.

In $16(33.3 \%)$ patients, the third and fourth repositioning procedure had to be applied due to persistence of vertiginous problems. Following the last repositioning procedure, there was significant improvement and even complete withdrawal of symptoms in all 48 (100\%) patients.

In $32(66.7 \%)$ patients, two repositioning maneuvers were sufficient for significant recovery, allowing them to do their usual activities. Complete withdrawal of symptoms after the second repositioning procedure has also been reported by other authors ${ }^{29,30}$.

The most important parameter for the interpretation of the results in clinical practice is the interaural $\mathrm{AR}^{31}$. We consider $\mathrm{AR} \geq 35 \%$ as clinically significant. It is interpreted as unilateral damage to the lower part of the labyrinth ${ }^{32-34}$. As a clinically significant parameter, we take the absolute value of the peak-to-peak amplitude, which is double in size of the other one.

The BPPV has a profound effect on function, independence and health-related quality of life. Beyond the unpleasant sensation of vertigo, BPPV negatively affects balance and increases the risk of falling ${ }^{35}$. As vertiginous disturbances negatively affect the healthrelated quality of life, we decided to examine which parameter of the oVEMPs (the only vestibular test that reflects utricle function) could indicate an increased likelihood of BPPV recurrence. The ROC method was selected as a simple way to assess differences in each indicator according to clinical recurrence; is determined on the basis of specificity and sensitivity. Our results are different from those reported by Lee et al. ${ }^{36}$ on a higher incidence of cVEMP abnormality in recurrent compared with non-recurrent BPPV cases. Zhou et al. ${ }^{37}$ found significant difference in the abnormal rate on oVEMP test between the recurrent and non-recurrent groups $(\mathrm{p}<0.01)$ but not in
cVEMP ( $p>0.05)$. So far, there is no study providing the wave complex parameters or cut-off value of cVEMP or oVEMP wave parameters that would point to the increased likelihood of recurrence.

According to our results, the oVEMP AR was the only significant diagnostic predictor of recurrence. The AR greater than $23 \%$ could indicate an increased incidence of vertiginous disturbances in patients. On follow up testing after six months, the patients with a value exceeding the cut-off value $(\mathrm{AR}>23 \%$ ) could be consulted to independently perform Brandt-Daroff's exercises at home to reduce the possibility of vertiginous disturbances recurrence and improve their quality of life.

\section{Conclusion}

The increase in the oVEMP amplitude on the affected side after successful repositioning procedure confirmed the hypothesis on the return of otoconia into the area of the utricular macula. We can also conclude that of all the VEMP parameters tested, oVEMP $A R$ was the only possible significant predictor of the future PC-BPPV recurrence.

\section{References}

1. Von Brevern M, Radtke A, Lezius F, Feldmann M, Zeise T, Lempert T, et al. Epidemiology of benign paroxysmal positional vertigo: a population based study. J Neurol Neurosurg Psychiatry. 2007;78:710-5.

2. Bašić Kes V, Čengić L, Cesarik M, Jadrijević Tomas A, Zavoreo I, Zadro Matovina L. Quality of life in patients with multiple sclerosis. Acta Clin Croat. 2013;52:107-11.

3. Dežmalj-Grbelja L, Čović-Negovetić R, Demarin V. Differential diagnosis and diagnostic algorithm of demyelinating diseases. Acta Clin Croat. 2009;48:345-8.

4. Honrubia V. Self-treatment of benign paroxysmal positional vertigo: Semont maneuver vs. Epley procedure. Neurology. 2005;64:583-4.

5. Braschi E, Ross D, Korownyk C. Evaluating the Epley maneuver. Can Fam Physician. 2015 Oct;61:878.

6. Silva CN, Ribeiro KM, Freitas RV, Ferreira LM, Guerra RO. Vertiginous symptoms and objective measures of postural balance in elderly people with benign paroxysmal positional vertigo submitted to the Epley maneuver. Int Arch Otorhinolaryngol. 2016;20:61-8. doi: 10.1055/s-0035-1565915

7. Yetiser S. A new variant of posterior canal benign paroxysmal positional vertigo: a nonampullary or common crus cana- 
lolithiasis. Case Rep Otolaryngol. 2015;2015:816081. doi: $10.1155 / 2015 / 816081$

8. Dorigueto RS, Mazzetti KR, Gabilan YP, Ganança FF. Benign paroxysmal positional vertigo recurrence and persistence. Braz J Otorhinolaryngol. 2009;75:565-72.

9. Talaat HS, Kabel AM, Khalil LH, Abuhadied G, El-Naga HA, Talaat AS. Reduction of recurrence rate of benign paroxysmal positional vertigo by treatment of severe vitamin $\mathrm{D}$ deficiency. Auris Nasus Larynx. 2016;43:237-41.

10. Brandt T, Huppert D, Hecht J, Karch C, Strupp M. Benign paroxysmal positioning vertigo: a long-term follow-up (6-17 years) of 125 patients. Acta Otolaryngol. 2006;126:160-3. doi: 10.1080/00016480500280140

11. Jones TA, Jones SM, Vijayakumar S, Brugeaud A, Bothwell M, Chabbert $\mathrm{C}$. The adequate stimulus for mammalian linear vestibular evoked potentials (VsEPs). Hear Res. 2011;280:133-40. doi: 10.1016/j.heares.2011.05.005.

12. Ribarić K, Prevec TS, Kozina V. Frequency-following response evoked by acoustic stimuli in normal and profoundly deaf subjects. Audiology. 1984;23:388-400.

13. Halmagyi GM, Black RA, Thurtell MJ, Curthoys IS. The human horizontal vestibulo-ocular reflex in response to active and passive head impulses after unilateral vestibular deafferentation. Ann NY Acad Sci. 2003;1004:325-36.

14. Welgampola MS, Myrie OA, Minor LB, Carey JP. Vestibularevoked myogenic potential thresholds normalize on plugging superior canal dehiscence. Neurology. 2008;70:464-72. doi: 10.1212/01.wnl.0000299084.76250.4a.

15. Piker EG, Jacobson GP, McCaslin DL, Hood LJ. Normal characteristics of the ocular vestibular evoked myogenic potential. J Am Acad Audiol. 2011;22:222-30. doi: 10.3766/jaaa.22.4.5.

16. Jacobson GP, McCaslin DL, Piker EG, Gruenwald J, Grantham SL, Tegel L. Patterns of abnormality in cVEMP, oVEMP, and caloric tests may provide topological information about vestibular impairment. J Am Acad Audiol. 2011;22: 601-11. doi: 10.3766/jaaa.22.9.5.

17. Rauch SD, Silveira MB, Zhou G, Kujawa SG, Wall C $3^{\text {rd }}$, Guinan JJ, et al. Vestibular evoked myogenic potentials versus vestibular test battery in patients with Meniere's disease. Otol Neurotol. 2004;25:981-6.

18. Iwasaki S, Ushio M, Chihara Y, Ito K, Sugasawa K, Murofushi T. Migraine-associated vertigo: clinical characteristics of Japanese patients and effect of lomerizine, a calcium channel antagonist. Acta Otolaryngol Suppl. 2007;559:45-9. doi: 10.1080/03655230701596491.

19. Rosengren SM, Govender S, Colebatch JG. Ocular and cervical vestibular evoked myogenic potentials produced by air- and bone-conducted stimuli: comparative properties and effects of age. Clin Neurophysiol. 2011;122:2282-9.

doi: 10.1016/j.clinph.2011.04.001.

20. Sreenivasan A, Sivaraman G, Parida PK, Alexander A, Saxena SK, Suria G. The clinical utility of vestibular evoked myogenic potentials in patients of benign paroxysmal positional vertigo.J Clin Diagn Res. 2015;9(6):MC01-MC03.

doi: $10.7860 / \mathrm{JCDR} / 2015 / 9953.6058$

21. Xu H, Liang FY, Chen L, Song XC, Tong MC, Thong JF, et al. Evaluation of the utricular and saccular function using oVEMPs and cVEMPs in BPPV patients. J J Otolaryngol Head Neck Surg. 2016 Feb 9;45:12.

doi: 10.1186/s40463-016-0125-7.

22. Seo T, Saka N, Ohta S, Sakagami M. Detection of utricular dysfunction using ocular vestibular evoked myogenic potential in patients with benign paroxysmal positional vertigo. Neurosci Lett. 2013;550:12-6. doi: 10.1016/j.neulet.2013.06.041.

23. Bremova T, Bayer O, Agrawal Y, Kremmyda O, Brandt T, Teufel J, Strupp M. Ocular VEMPs indicate repositioning of otoconia to the utricle after successful liberatory maneuvers in benign paroxysmal positioning vertigo. Acta Otolaryngol. 2013;133:1297-303. doi: 10.3109/00016489.2013.829922.

24. Schuknecht HF, Gacek MR. Cochlear pathology in presbycusis. Ann Otol Rhinol Laryngol. 1993;102:1-16. doi: $10.1177 / 00034894931020 \mathrm{~S} 101$

25. Lo W, Daniels DL, Chakeres DW, Linthicum FH Jr, Ulmer JL, Mark LP, Swartz JD. The endolymphatic duct and sac. AJNR Am J Neuroradiol. 1997;18:881-7.

26. Scheerer WD, Hildmann H. Comparative studies of the endolymphatic sac and duct in embryonic skull (author's transl). Arch. Otorhinolaryngol. 1979;222:175-80.

27. Singh NK, Apeksha K. Efficacy of cervical and ocular vestibular-evoked myogenic potentials in evaluation of benign paroxysmal positional vertigo of posterior semicircular canal. Eur Arch Otorhinolaryngol. 2015;36:261-8. doi: 10.1007/s00405-015-3867-3.

28. Damman W, Kuhweide R, Dehaene I. Benign paroxysmal positional vertigo (BPPV) predominantly affects the right labyrinth. J Neurol Neurosurg Psychiatry 2004;75:1487-8.

29. Blatt PJ, Georgakakis GA, Herdman SJ, Clendaniel RA, Tusa RJ. The effect of the canalith repositioning maneuver on resolving postural instability in patients with benign paroxysmal positional vertigo. Am J Otol 2000;21:356-63.

30. Ruckenstein MJ. Therapeutic efficacy of the Epley canalith repositioning maneuver. Laryngoscope. 2001;111:940-5. doi: 10.1097/00005537-200106000-00003

31. Singh NK, Barman A. Efficacy of ocular vestibular-evoked myogenic potential in identifying posterior semicircular canal benign paroxysmal positional vertigo. Ear Hear. 2015;36: 261-8. doi: 10.1097/AUD.0000000000000097.

32. Brantberg K, Fransson PA. Symmetry measures of vestibular evoked myogenic potentials using objective detection criteria. Scand Audiol. 2001;30:189-96.

33. Welgampola MS, Colebatch JG. Characteristics of tone burstevoked myogenic potentials in the sternocleidomastoid muscles. Otol Neurotol. 2001;22:796-802.

34. Miyamoto A, Seo T, Node M, Hashimoto M, Sakagami M. Preliminary study on vestibular-evoked myogenic potential in- 
duced by bone-conducted stimuli. Otol Neurotol. 2006;27: 1110-4. doi: 10.1097/01.mao.0000231599.33585.c6

35. Parham K, Kuchel GA. A geriatric perspective on benign paroxysmal positional vertigo. J Am Geriatr Soc. 2016;64:378-85. doi: 10.1111/jgs.13926.

36. Lee JD, Park KM, Lee BD, Lee TK, Sung KB, Park JY. Abnormality of cervical vestibular-evoked myogenic potentials and ocular vestibular-evoked myogenic potentials in patients with recurrent benign paroxysmal positional vertigo. Acta Otolaryngol. 2013;133:150-3.

37. Zhou X, Yu Y, Wu Z, Liu X, Chen X. The roles of otolith organs in the recurrence primary benign paroxysmal positional vertigo. Lin Chung Er Bi Yan Hou Tou Jing Wai Ke Za Zhi. 2015;29:1641-4.

Sažetak

\title{
ULOGA VESTIBULARNIH EVOCIRANIH MIOGENIH POTENCIJALA KAO POKAZATELJA STANJA OPORAVKA KOD BOELSNIKA S DOBROĆUDNOM PAROKSIZMALNOM POLOŽAJNOM VRTOGLAVICOM
}

\author{
T. Mendeš, S. Maslovara, A. Véeva i S. Butković Soldo
}

Okularni vestibularni evocirani mišićni potencijali (oVEMP) i cervikalni VEMP (cVEMP) su novije dijagnostičke metode koje omogućuju uvid u stanje otolitičkih osjetila. Cilj je bio utvrditi postoje li promjene u određenim parametrima VEMP valnog kompleksa nakon uspješno provedenog Epleyjeva repozicijskog postupka, koje bi bile pokazatelji stanja oporavka bolesnika s dobroćudnom paroksizmalnom položajnom vrtoglavicom (BPPV). To bi potvrdilo teoriju o povratku otolita u područje otolitičkih osjetila. Sekundarni cilj istraživanja bio je utvrditi značenje pojedinih parametara VEMP kompleksa kao prediktora mogućih recidiva bolesti. Ispitivanje je uključilo 48 bolesnika s jednostranim BPPV stražnjega polukružnog kanalića. Pri prvom pregledu u sklopu cjelokupne otoneurološke obrade učinjene su im pretrage oVEMP i cVEMP. Ovo je ponovljeno i na pregledima kojima su bolesnici pristupili sedam dana i šest mjeseci nakon uspješno provedenog Epleyjeva postupka. Pri prvom mjerenju uočeno je značajno smanjenje amplitude oVEMP zahvaćene strane, izraženo kroz povećani omjer amplituda. U drugom mjerenju uočen je porast amplitude zahvaćene strane, dok je omjer amplituda posljedično smanjen $(\mathrm{p}=0,693)$, a statistički značajno smanjen pri završnom pregledu nakon 6 mjeseci $(\mathrm{p}=0,006)$. Značajno povećanje amplitude oVEMP zahvaćene strane nakon uspješnog repozicijskog postupka potvrđuje hipotezu o povratku otolita u području makule utrikulusa.

Ključne riječi: Vestibularni evocirani miogenski potencijali; Otolitna membrana; Benigna paroksizmalna pozicijska vrtoglavica; Semicirkularni kanali; Kvaliteta života 